This item was submitted to Loughborough's Research Repository by the author.

Items in Figshare are protected by copyright, with all rights reserved, unless otherwise indicated.

\title{
Tracing the sculptural legacy of Constance Naden: Memorialisation, gender, and the portrait bust
}

PLEASE CITE THE PUBLISHED VERSION

https://doi.org/10.1093/jvcult/vcy046

\section{PUBLISHER}

(C) Leeds Trinity University. Published by Oxford University Press (OUP)

\section{VERSION}

AM (Accepted Manuscript)

\section{PUBLISHER STATEMENT}

This is a pre-copyedited, author-produced version of an article accepted for publication in Journal of Victorian Culture following peer review. The version of record PARKER, S.L. and STAINTHORP, C., 2018. Tracing the sculptural legacy of Constance Naden: Memorialisation, gender, and the portrait bust. Journal of Victorian Culture, 23(4), pp. 508-526 is available online at: https://academic.oup.com/jvc/article/23/4/508/5042854 and https://doi.org/10.1093/jvcult/vcy046.

\section{LICENCE}

CC BY-NC-ND 4.0

\section{REPOSITORY RECORD}

Parker, Sarah, and C. Stainthorp. 2018. "Tracing the Sculptural Legacy of Constance Naden: Memorialisation, Gender, and the Portrait Bust”. figshare. https://hdl.handle.net/2134/33475. 


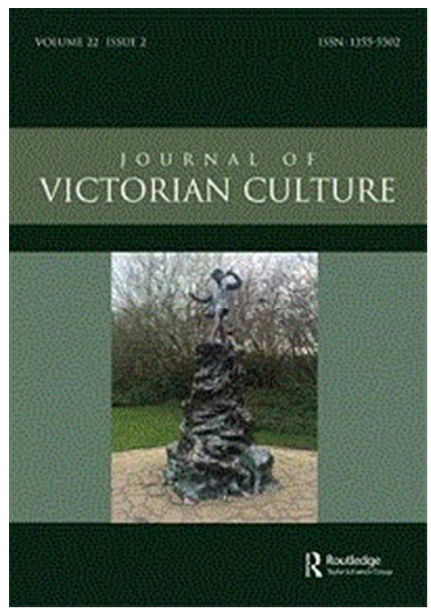

\section{Tracing the Sculptural Legacy of Constance Naden: Memorialisation, Gender and the Portrait Bust}

\begin{tabular}{|r|l|}
\hline Journal: & Journal of Victorian Culture \\
\hline Manuscript ID & RJVC-2017-0025.R2 \\
\hline Manuscript Type: & Original Article \\
\hline Keywords: & $\begin{array}{l}\text { Constance Naden, sculpture, University of Birmingham, women's } \\
\text { education, women poets, material culture, civic identity, portraiture, } \\
\text { portrait bust }\end{array}$ \\
\hline \multicolumn{2}{|l}{} \\
\hline
\end{tabular}

\section{SCHOLARONE ${ }^{\text {m }}$}

Manuscripts 
Title: Tracing the Sculptural Legacy of Constance Naden: Memorialisation, Gender, and the Portrait Bust

Word count: 8539

Word count without endnotes: 7029 


\begin{abstract}
This article traces the history of the Constance Naden memorial bust, commissioned in 1890 and now held in the Cadbury Research Library at the University of Birmingham. We describe the commissioning, funding and creation process, and analyse its purpose in terms of memorialisation, its negotiation of gender, and how it portrays Naden as a poet, philosopher and scientist. The enduring legacies of, and reactions to the bust, are considered in the context of Birmingham's Mason Science College, where Naden studied between 1881 and 1887 . We argue that Naden's bust is symptomatic of the University of Birmingham establishing its identity and that the subsequent changes in its location within the institution signify the shifting role of Naden within that legacy. Our reading of this sculptural artefact leads to several broader observations regarding poetic identity, gender, genius and female education, the establishment of universities and consolidating of civic identities via sculpture, and the memorialisation of the poet. While a surface reading of the bust obscures the multifaceted nature of Naden's intellectual career, by attending to it more closely, turning the object on its plinth and locating it in its physical contexts over time, a far richer and more accurate view of the object, the person, and her place in history becomes apparent.
\end{abstract}

Keywords: Constance Naden; sculpture; University of Birmingham; women's education; women poets; material culture; civic identity 


\section{Tracing the Sculptural Legacy of Constance Naden: Memorialisation, Gender and the Portrait Bust}

'I have shown the outward frame, Tell me now the maiden's name.'

'A Portrait', Constance Naden's short unpublished poem composed as an adolescent between 1875 and 1877, offers a feature-by-feature description of a woman's physical characteristics. It closes with the above couplet, which turns the seemingly simplistic poem into a riddle. The answer is certainly Naden herself. Less than fifteen years after the poem was composed, Naden was dead and a marble bust (figure 1) had been created that immortalised her 'outward frame'. Yet for much of the sculpture's existence those encountering the object would have been hard-pressed to recognise the woman it memorialised. Although her name and the titles of her books are inscribed into the bust's base, the twentieth century was not kind to Naden's memory. The sculptural object that originally elicited remembrance and symbolised the University of Birmingham's intellectual tradition took on alternative decorative and talismanic functions in the twentieth and twenty-first centuries.

This article traces the history of the Constance Naden bust (now situated in the Cadbury Research Library, University of Birmingham), documenting the commissioning, funding and creation process to analyse its purpose in terms of memorialisation, its negotiation of gender, and how it portrays Naden as a poet, philosopher and scientist. Reactions to the bust and its legacies are analysed in the context of higher education in Birmingham. We argue that Naden's bust is symptomatic of Mason Science College, later the University of Birmingham, establishing its identity; the bust's movements signify the shifting role of Naden within that history. We also consider the portrayal of Naden's bust in light of Herbert Spencer's assessment that her early death was due to highly-developed unfeminine 'mental powers'. ${ }^{2}$ Our close attention to this sculptural artefact leads to broader observations regarding poetic identity, gender, genius and female education, the establishment of universities and consolidation of civic identities via sculpture, and the memorialisation of the poet.

\footnotetext{
${ }^{1}$ Constance Naden, 'A Portrait', Poems; by Constance C. W. Naden. 1875-6-7, Birmingham, Cadbury Research Library, USS 115, p. 82.

2 'Letter from Herbert Spencer to Dr. Lewins, June 10th, 1890', in Constance Naden: A Memoir, ed. by William R. Hughes (London: Bickers \& Son; Birmingham: Cornish Brothers, 1890), pp. 89-91 (p. 90).
} 
Sculpture has recently become a higher profile concern within nineteenth-century studies, in part due to the material turn evidenced by the rise of thing theory and scholarship on tactility. ${ }^{3}$ A 2016 special issue of 19 addressed 'the place of sculpture in Victorian culture: hauntingly present but rarely interrogated, monumental yet mundane, and, above all, disconcertingly difficult to read'. ${ }^{4}$ The wide-ranging exhibition 'Sculpture Victorious: Art in an Age of Invention, 1837-1901' brought Victorian sculpture firmly onto the public stage at the Yale Center for British Art in 2014 and at Tate Britain (London) in 2015. This exhibition was received poorly by critics, who viewed it as overly ambitious and confusingly eclectic. One reviewer complained of being overwhelmed by the proliferation of busts of Queen Victoria: 'there's no getting away from her: young, old, big, small, enlarged, reduced, carved in marble and ivory, cast in bronze and porcelain - her multiple selves crowd the first room., 5

For scholars, however, the exhibition showed precisely why Victorian sculpture is fascinating; its diversity, innovation, and enthusiastic adoption of new technologies facilitating 'the reproduction of elite works of sculpture [...] expanding their reach to a large middle-class market as private objects for domestic spaces' ${ }^{6}$ Despite the rarefied nature of its construction - a pencil or box of watercolours are far more accessible than a block of marble - sculpture can be considered the epitome of public art, positioned on thoroughfares and the exterior of buildings. But the mixed reception of Sculpture Victorious demonstrates that many still struggle to read Victorian sculpture, particularly the portrait bust. This article addresses this issue in relation to the Naden bust, using it as a case study to ask: how can one read the sculptural bust within the various contexts of its creation, the longer history of commemorative busts, and in terms of its afterlives? How does such sculptural memorialisation contribute to the public image of the poet, and of the female intellectual?

\section{Naden's life and death}

Naden was born in Birmingham in 1858. She was brought up by her maternal grandparents, wealthy through the local jewellery industry, at the behest of her mother who died within days of giving birth; her father remarried a couple of years later. Naden's upbringing granted

\footnotetext{
${ }^{3}$ See Jennifer Sattaur, 'Thinking Objectively: An Overview of "Thing Theory” in Victorian Studies', Victorian Literature and Culture, 40.1 (2012), 347-57.

${ }^{4}$ Angela Dunstan, 'Reading Victorian Sculpture', 19: Interdisciplinary Studies in the Long Nineteenth Century, 22 (2016), 1-14, DOI: 10.16995/ntn.776

5 Adrian Searle, 'Sculpture Victorious review', Guardian, 23 February 2015

$<$ https:/www.theguardian.com/artanddesign/2015/feb/23/sculpture-victorious-review-tate-britain $>$ [accessed 7 March 2018]

${ }^{6}$ Martina Droth, Jason Edwards, and Michael Hatt, 'Introduction,' Sculpture Victorious: Art in an Age of Invention, 1837-1901 (New Haven: Yale University Press, 2014), p. 56.
} 
her independence. Rather than expecting their granddaughter to support herself financially or find a husband to do so, Josiah and Caroline Woodhill encouraged her desire to learn. Today, Naden is best known as a poet; selections from her two poetic volumes featured in anthologies of Victorian women's poetry published during the 1990s and early 2000s. This has led to a steady stream of research into her works, most of which situates her as an explicitly female voice addressing scientific concerns. Marion Thain and Andrea Kaston Tange have delineated how Naden reflected upon shifting gender roles through the interplay between arch social commentary and intimate knowledge of scientific developments. ${ }^{7}$ Charles LaPorte and Nour Alarabi have built upon these connections, situating Naden's poetry in the context of freethinking, interdisciplinary movements of the period. ${ }^{8}$

In her lifetime and immediately after, however, Naden was also known as a trailblazer within social science and philosophy. She was elected as the first female Associate of Mason College (having excelled in wide-ranging science study between 1881 and 1887), was welcomed into London's philosophical Aristotelian Society, and frequently wrote about social evolution and her atheist philosophy in periodicals. She was an advocate of reform and supported several causes that sought to benefit the position of women. Naden is nonetheless absent from contemporary scholarship on the history of ideas, although recent work by Clare Stainthorp has challenged this elision by arguing that Naden's interdisciplinary endeavours in poetry, philosophy and science provide a lens through which to better understand Victorian resistance to the fragmentation of knowledge. ${ }^{9}$

For Naden, the three facets of her intellectual endeavour were interlinked and reciprocal, and so her works can only be fully understood through an interdisciplinary perspective encompassing the breadth of her corpus. ${ }^{10}$ Naden weaves both philosophical and scientific concerns into her poetry. In Songs and Sonnets of Springtime (1881), she interrogates religious belief to illuminate her developing secular, materialist philosophy Hylo-Idealism - while the comic 'Evolutional Erotics' of A Modern Apostle (1887) consider

\footnotetext{
${ }^{7}$ Marion Thain, “'Scientific Wooing”: Constance Naden's Marriage of Science and Poetry', Victorian Poetry 41.1 (2003), 151-169; Andrea Kaston Tange, 'Constance Naden and the Erotics of Evolution: Mating the Woman of Letters with the Man of Science', Nineteenth-Century Literature, 61.2 (2006), 200-40.

${ }^{8}$ Charles LaPorte, 'Atheist Prophecy: Mathilde Blind, Constance Naden, and the Victorian Poetess', Victorian Literature and Culture, 34 (2006), 427-41; Nour Alarabi, 'Constance Naden's Philosophical Poetry', Literature Compass 9.11 (2012), 848-60.

${ }^{9}$ Clare Stainthorp, Constance Naden: Scientist, Philosopher, Poet (Bern: Peter Lang, forthcoming 2019).

${ }^{10}$ For a discussion of how this perspective arises out of existing research on Naden, see Clare Stainthorp, 'Constance Naden: A Critical Overview', Literature Compass, 14.8 (2017).
} 
human relationships from the perspective of Darwinian sexual selection. ${ }^{11}$ In her essays, Naden draws upon poetic rhetorical techniques to make claims for human creativity as integral to understanding the universe. She concludes that 'matter, untouched, unseen, unperceived by sensation or thought, must be a void and formless chaos, until the first living eye gives it shape and colour, the first living organ of touch endows it with tangible solidity, the first living ear wakes the dumb to speech and song, ${ }^{12}$

Naden died, aged thirty-one, on 23 December 1889, and obituaries celebrated her diverse achievements. However, it was a letter of condolence written by Spencer in June 1890 that came to define her legacy. Its intention is laudatory: he compares Naden favourably with George Eliot, stating that he could think of no other women 'in whom there has been this union of high philosophical capacity with extensive acquisition' and arguing that Naden's 'subtle intelligence would have done much in furtherance of rational thought; her death has entailed a serious loss'. He nonetheless concludes that 'in her case, as in other cases, the mental powers so highly developed in a woman are in some measure abnormal, and involve a physiological cost which the feminine organization will not bear without injury more or less profound'. ${ }^{13}$ Spencer thus suggests that Naden died of complications to do with ovarian cysts because her body could not support the brain work that she had undertaken with such confidence and ability.

This, unsurprisingly, angered many people. Madeline Daniell, Naden's friend and travelling companion, wrote a letter of rebuke: 'Miss Naden's lamented death was not caused by her exceptional mental development', indeed 'It was the strength and healthiness of her brain which kept her spirits even, and allowed her to work without evil effects' during her protracted illness. Daniell argues that such 'highly developed mental powers' may only be considered 'abnormal' in that they are uncommon in either sex, and concludes: 'Mr. Spencer's words carry much weight, and have much influence, therefore I have been constrained to write so that no false impression may go abroad'. ${ }^{14}$ While others echoed

\footnotetext{
${ }^{11}$ Constance C. W. Naden, Songs and Sonnets of Springtime (London: C. Kegan Paul, 1881); Constance C. W. Naden, A Modern Apostle; The Elixir of Life; The Story of Clarice; and Other Poems (London: Kegan, Paul, Trench, 1887).

${ }^{12}$ Constance Naden, 'The Brain Theory of Mind and Matter; or, Hylo-Idealism. Journal of Science, March, 1883', in Induction and Deduction: A Historical and Critical Sketch of Successive Philosophical Conceptions Respecting the Relations Between Inductive and Deductive Thought and Other Essays, ed. by Robert Lewins (London: Bickers and Son, 1890), pp. 156-66 (p. 166).

13 'Letter from Herbert Spencer', pp. 89; 90.

${ }^{14}$ Madeline Daniell, ‘A Point Omitted', Women's Penny Paper, 5 July 1890, p. 439.
} 
Daniell's disapproval, Spencer's words nonetheless came to be repeated as proof of women's unfitness for intellectual activities into the twentieth century. ${ }^{15}$

Naden was buried in a modest grave shared by her mother and maternal grandparents; the inscription does not indicate her achievements, only her parents' names, her death date, and the age at which she died. The creation of the bust therefore provided Naden with a fitting public memorial that celebrated her intellectual endeavour. This project was undertaken by Robert Lewins, a retired army surgeon who had been her friend, intellectual collaborator and editor since 1876 . He believed that Naden should be rightfully remembered as a philosopher, poet and scientific thinker. In Constance Naden: A Memoir, he wrote that their shared Hylo-Idealism - an atheist synthesis of idealism and materialism 'based exclusively on well-established data of Physics, Physiology, and Moral Philosophy' 'coloured and inspired all her utterances, in prose or rhyme' ${ }^{16}$

Lewins funded the bust and founded the 'Constance Naden Gold Medal', to be awarded annually to a Mason College student for an essay on a philosophical subject. ${ }^{17} \mathrm{He}$ moved rapidly in these commissions: a transcript of a letter dated 6 January 1890 shows that Lewins had already decided to commemorate Naden with both a bust and medal, originally suggesting that a Mr Williamson would take on the sculpture commission. ${ }^{18}$ Not long afterwards, however, William Henry Tyler began working on both projects. A London correspondent of the Sheffield Daily Telegraph stated that she had seen 'a rough clay cast' in Tyler's studio on 25 January. ${ }^{19}$ There is little information to be found regarding Tyler's life and career; he was from Worcester and in The Benezit Dictionary of Artists he is listed as a sculptor 'predominantly [of] busts' who was 'active in the second half of the nineteenth century' and 'exhibited in London from 1878 to 1893 '. ${ }^{20}$ He exhibited fifteen pieces at the Royal Academy of Arts Summer Exhibition between 1878 and 1893, his most well-known piece being a bust of celebrated cricketer W. G. Grace. ${ }^{21}$

\footnotetext{
${ }^{15}$ Apologists for Spencer include Havelock Ellis, Man and Woman: A Study of Human Secondary Sexual Characteristics, $4^{\text {th }}$ edition (London: Walter Scott Publishing, 1904), p. 212.

${ }^{16}$ Robert Lewins, 'IV', in Memoir, pp. 71-86 (pp. 72; 71), original emphasis.

${ }^{17}$ The prize continues to be awarded by the University of Birmingham to the author of the best humanities research master's dissertation.

18 'Extract from Mason College Council Minutes', Cadbury Research Library, LAdd/541. Likely Francis John Williamson (1833-1920), who sculpted the Thomas Heslop bust (1886; eventually paired with Naden), the Birmingham monument to George Dawson and Joseph Priestly, and a bust of Alfred Lord Tennyson (1893). 'Francis John Williamson', in The Benezit Dictionary of Artists, 14 vols (Paris: Gründ, 2006), XIV, p. 939.

19 'From our Lady Correspondent. London, Wednesday', Sheffield Daily Telegraph, 30 January 1890, p. 5.

20 'William H. Tyler', in Benezit Dictionary, XIII, p. 1300. Further information can be found in the Mapping the Practice and Profession of Sculpture in Britain \& Ireland 1851-1951 database

$<$ http://sculpture.gla.ac.uk/view/person.php?id=msib4_1256302512> [accessed 20 March 2018]

21 Ibid.
} 
The correspondent claims that even in the rough cast Tyler had succeeded in 'delineat[ing] in the expression of the face the distinguishing traits of the young scholar and poetess'. Tyler had not made Naden's acquaintance during her lifetime, however, and created the sculpture on the basis of 'a careful study of her character from her poems and the facts of her life' as well as referring to 'a cast of the face taken after her death and the capital likeness taken in Birmingham,. ${ }^{22}$ This photograph (figure 2 ) is a regularly reproduced portrait taken in 1887, prior to Naden's trip to India (her friends feared she may not survive the change of climate). While the rationale for her travels with Daniell is not certain, she conceivably visited India to expand her knowledge of non-Western philosophical traditions; Naden met 'several of the native pundits' to whom she was introduced by Max Müller. ${ }^{23}$ An engraving by G. J. Stodart, which served as the frontispiece to Hughes's Memoir of Naden (1890), is taken from an unpublished photograph from the same sitting in which Naden is standing (see figure 3).

The finished bust is classical in style, with drapery around the shoulders and a lyre at the base; an inscription from the Aeniad appears on the pedestal. The most striking element is the plinth, which is formed of three stacked books: two of the spines face forwards, bearing the names of her two volumes of poetry along with 'C. C. W. Naden', the third spine is turned away and reads 'Induction and Deduction / Hylo-Idealism' (figure 4). The choice and positioning of these specific volumes, as well as the Hellenic appearance of Naden's bust, suggests the aspects of her career that Lewins, via Tyler, wished to emphasise. Before expanding upon these matters, the next section considers the Naden bust in the context of the sculptural memorialisation of poets.

\section{II. 'Moment's monument': Poets and the portrait bust}

As Angela Dunstan observes, the sculptural bust is 'an embodied signifier of bodily absence', as concerned with signifying loss as retaining presence. ${ }^{24}$ The bust not only stands in for the literal loss of the deceased's body, but the sculpted, disembodied head emphasises the cerebral over the corporeal. It is therefore a form eminently suited to commemorating philosophers, politicians and writers. Lewins's commission of a posthumous bust of Naden participates in a classical form of memorialisation and celebration. The tradition of representing poets via sculpted busts began in the fifth century BC. Ancient Greek busts, and

\footnotetext{
22 'Lady Correspondent', 30 January 1890.

${ }^{23}$ Memoir, p. 42.

${ }^{24}$ Dunstan, p. 1.
} 
later Roman copies, were supposed to represent 'ideal' types. ${ }^{25}$ The famous first-century-AD bust of Homer originally stood in the Library of Pergamum. The tradition of library busts was revived in the eighteenth century by neoclassical enthusiasts; a 'canon of worthies' - such as Trinity College Dublin's set of marble busts by celebrated French sculptor Louis-François Roubiliac - became popular, with busts grouped to signify political allegiances, celebrate military prowess, communicate national pride, or embody virtues. ${ }^{26}$ As well as serving as markers for different areas of the library, the busts' purpose was to inspire people to emulate the heroic and the learned. Throughout the eighteenth and early nineteenth century, most well-equipped libraries had a set of poet busts, including Shakespeare, Milton, Dryden and Pope. ${ }^{27}$ The eighteenth-century politician Lord Bolingbroke argued that this use of sculpture derived from the Roman tradition of domestic effigies, their purpose being to recall 'the glorious actions of the dead to fire the living, to excite them to imitate, and even to emulate, their great forefathers'. ${ }^{28}$ These 'venerable busts' anticipate the role later attributed to the National Portrait Gallery. Founded in 1859, it sought to inspire the public with images of celebrated individuals 'whose example we are more induced to imitate when they are brought before us in the visible and tangible shape of portraits'. ${ }^{29}$

The memorialising and celebratory role of the portrait bust is nowhere more apparent than Poets' Corner in Westminster Abbey. Chaucer was buried there in 1400, and during the first half of the eighteenth century the area became populated with male poets' busts.

Notably, at the time of Naden's death no women were memorialised there, and of the few women now in Poets' Corner, none have been honoured with a bust or statue (save Margaret Cavendish, who appears on a marble tomb with her husband). Ironically, given its alignment with memorialisation, David Getsy argues that deathliness is a residual risk in sculpture: 'For centuries, sculptors have resisted the immotility of sculpture in order to imbue their works with life. The most biting criticism of figurative sculpture is to call it cold and lifeless. ${ }^{30}$ The

\footnotetext{
${ }^{25}$ David Piper, The Image of the Poet: British Poets and their Portraits (Oxford: Oxford University Press, 1982), p. 6.

${ }^{26}$ Penelope Curtis, Peter Funnell and Nicola Kalinsky, 'Introduction', in Return to Life: A New Look at the Portrait Bust, ed. by Penelope Curtis, Peter Funnell and Nicola Kalinsky (Leeds: The Henry Moore Institute, 2000), p. 8.

${ }^{27}$ Piper, p. 78.

${ }^{28}$ Qtd. in Malcolm Baker, “"A Sort of Corporate Company”: The Portrait Bust and Its Setting', in Return to Life, pp. 20-35 (p. 23).

${ }^{29}$ Lord Palmerston qtd. in Malcolm Rogers, Camera Portraits: Photographs from the National Portrait Gallery 1839-1989 (New York: Oxford University Press, 1990), p. 9. The gallery's first acquisition - the Chandos portrait of William Shakespeare - shows how the image of the poet contributed to this sense of British national identity.

${ }^{30}$ David Getsy, Body Doubles: Sculpture in Britain, 1877-1905 (New Haven: Yale University Press, 2004), p. 134. Getsy's discussion concerns the challenging Shelley Memorial (Edward Onslow Ford, 1892), which
} 
sculptural bust thus embodies a contradiction; this stationary, uncannily disembodied head seeks to immortalise its subject while paradoxically resembling a death mask.

Lord Byron expressed his ambivalence about the portrait bust, despite sitting for several during his lifetime. After posing for Bertel Thorvaldsen in 1817, he writes: 'I won't have my head garnished like a Christmas pie with holly [...]. I wonder you should want me to be such a mountebank. ${ }^{31}$ Byron's complaints anticipate the declining popularity of the form in the twentieth century. Busts came to seem hackneyed, partly due to their alienating classicism - the conventional blank eyes, laurels and drapery - and monochromatic lack of colour (usually the white of marble or porcelain, or darker hues of black limestone or bronze). As Malcolm Baker has observed, busts seem 'at once very familiar yet distant', familiar in their clichéd antiquity yet somehow alienating in their uniformity. ${ }^{32}$ In the twentyfirst century, the portrait bust is often overlooked, viewed as a decorative accessory evoking non-specific old-fashioned grandeur. But, as Baker argues, we can reinvigorate our response to the bust by looking more carefully at how it is positioned: walking around it, viewing it up close and from a distance, and pausing to consider the kinship of bust groups. Busts solidify institutional power, 'they together reinforce the impression of belonging [...] we register them collectively, as part of the building that speaks of institutional authority, ${ }^{33}$ The location, position and intended viewers of busts all contribute to their public and private functions; these can be decoded to discern the artefact's deeper meaning. Bearing in mind these approaches, a closer look at the Naden bust - both literal and figurative - proves instructive. The following sections analyse the formation of the bust close-up and at a distance, considering its significant position within the history of Birmingham and in terms of theories of physiognomy and ideas of female poetic identity.

\section{The Naden bust}

Through the Naden bust's form and positioning we can read both the subject's life and the history of the University of Birmingham. It was created to stand in Mason College as a memorial to Naden's contribution to the fledgling institution: she studied there for six years and was heavily involved in its activities throughout the 1880 s, including editing and contributing to the student magazine. The co-educational college provided equal

presents the viewer with the poet's realistically rendered corpse, overturning the expectations of idealisation in the service of 'immortalisation'.

${ }^{31}$ Qtd. in Piper, p. 138.

${ }^{32}$ Baker, p. 20.

${ }^{33}$ Ibid., p. 21. 


\footnotetext{
${ }^{34}$ While most high-achieving students entered University of London degree exams, Naden instead chose to continue classes at Mason College for six years; this decision cemented her place in the history of the institution.

${ }^{35}$ Baker, p. 25.

${ }^{36}$ Marion Thain, 'Birmingham Women Poets: Aestheticism and the Daughters of Industry', Cahiers victoriens \& édouardiens, 74 (2011), 37-57.

${ }^{37}$ Josiah Mason, 'Deed of Foundation of The Mason Science College. $12^{\text {th }}$ December 1870 ', Birmingham, Cadbury Research Library UB/MC/G/1/1, p. 21.

38 'Lady Correspondent', 30 January 1890.

${ }^{39}$ John Gage, 'Busts and Identity', in Return to Life, pp. 36-48 (p. 38).
} 
others. ${ }^{40}$ Other studies measured creativity: James DeVille owned a life mask of William Blake, which he used as 'representative of the imaginative faculty' in his phrenological analyses. $^{41}$

Gage claims that in 'the patriarchal society of Victorian England women were generally excluded from these phrenological speculations, just as they appear relatively rarely as a subject for busts'. ${ }^{42}$ This statement requires modification, Queen Victoria being a frequent subject for busts. Whilst rarer than those of men, extant busts of women writers include Felicia Hemans (Angus Fletcher, 1829), Mary Shelley (Camillo Pistrucci, 1843), and Elizabeth Barrett Browning (William Wetmore Story, 1861). Nonetheless, it was relatively unusual for female intellectuals to be commemorated in this way. As Lara Perry notes, a high proportion of the portraits of women writers in the National Portrait Gallery are in 'minor' media: 'watercolours, pastels, pencil sketches and miniatures [...] smaller, and often monochromatic, the collection of nineteenth-century women authors' portraits tended to ascribe them with what was literally a minimum of material presence' ${ }^{43}$ In the context of how female intellectuals were commemorated, then, Naden's bust can be read as an emphatic statement of her significance; a material marker that sought to place her firmly alongside her male intellectual peers.

To return to Gage's statement, women were subject to 'phrenological speculations', rather than excluded from them. For example, Johann Gasper Spurzheim observed that the organs of 'circumspection and secretiveness' are 'more generally active in the female than the male' in his chapter 'Of the Heads of the Sexes', while the skulls of female criminals featured in studies of degeneration. ${ }^{44}$ Women writers were also phrenologically assessed. Charles Bray took George Eliot to have a cast made of her skull in 1844, observing that 'the social feelings were very active, particularly the adhesiveness'. ${ }^{45}$ Combe considered her skull perfect, but subsequently retracted his comments following Eliot's relationship with George Henry Lewes, describing her as mad and degenerate. ${ }^{46}$ Naden later met Bray, an 'immense

\footnotetext{
${ }^{40}$ George Combe, Phrenology applied to Painting and Sculpture (London: Simpkin, Marshall, 1885).

41 'William Blake by James Deville', National Portrait Gallery: http://www.npg.org.uk/collections/search/portrait/mw00611/William-Blake

42 Gage, p. 45.

${ }^{43}$ Lara Perry, History's Beauties: Women and the National Portrait Gallery, 1856-1900 (Aldershot, Hants: Ashgate, 2006), p. 81.

${ }^{44}$ Johann Gaspar Spurzheim, Phrenology, in Connexion with the Study of Physiognomy: Part I: Characters (London: Treuttel, Wurtz and Richter, 1826), p. 41.

${ }^{45}$ Charles Bray, Phases of opinion and experience during a long life: an autobiography (London: Longmans, Green, 1884), p. 75.

${ }^{46}$ See Kathryn Hughes, George Eliot: The Last Victorian (London: Fourth Estate, 1998), p. 153.
} 
${ }^{47}$ Hughes, Memoir, p. 4.

${ }^{48}$ Hughes, Memoir, p. 60.

${ }^{49}$ Bray, p. 74.

50 'Letter from Herbert Spencer', p. 90.

${ }^{51}$ Lyssa Randolph discusses this issue in relation to the intertwined public response to the deaths of Naden and Amy Levy in 1889, 'Verse or Vitality? Biological Economies and the New Woman Poet', in Amy Levy: Critical Essays, ed. by Naomi Hetherington and Nadia Valman (Athens, OH: Ohio University Press, 2010), pp. 198-220.

${ }^{52}$ See image on the Nuneaton Museum website:

$<$ https://www.search.windowsonwarwickshire.org.uk/details.aspx?ResourceID=11654> [accessed 18 April 2018]

53 'Lady Correspondent', 30 January 1890. 
Above the narrow book-base, the classical swath of material thrown over her shoulders blends into the gown towards the base of the bust, gathering around the socle. Beneath this drapery, Naden is depicted wearing a square-necked, slightly gathered gown, in keeping with aesthetic fashions in the late 1890s. This is surprising, not only because it is more contemporary than we might expect from a bust, but because, as Thain has observed, 'one would be hard pushed to class Naden as an aesthete'. ${ }^{54}$ The original photograph on which the bust is based (in which Naden wears the same dress as that in Fig. 2) - and Stodart's engraving [Fig. 3] - depict Naden in a more conventional gown: high-necked, with bows at the cuffs and neck, a large brooch at the throat, cross and bracelets. Tyler's bust omits these sartorial details in favour of a refined classical simplicity with an air of the aesthetic.

The classicism of the bust cements Naden's place within an august lineage of creative thinkers. It is at odds, however, with the industrial modernity of Mason College. The institution taught science, which had only recently become an accepted academic discipline (rather than the subject of amateur and industrial experiment). As a result, Mason College was seeking to establish its position. Situating Naden's bust in the library, paired with that of Thomas Heslop (Professor of Physiology, first chairman of the College and donor of most of the library's original collection) gave an impression of history and tradition, building a sense of the institution's own legacy. ${ }^{55}$

In October 1892, a short article in the Birmingham Daily Post reported:

Dr. Robert Lewins [...] has just supplemented his donation of the bust of Miss Naden by a handsome Greek black scagliola Theseus pedestal, bearing the following inscription: 'Constance C. W. Naden, born January 24, 1858, died December 23, 1889. "Sunt lacrimae rerum et mentem mortalia tangunt." The pedestal was executed by Mr. William Tyler, of London, the sculptor of the bust, who has recently visited Birmingham, and placed the bust in position. ${ }^{56}$

Scagliola is an imitation marble made from painted and/or polished dyed plaster. The term 'Theseus pedestal' refers to the shape of the top piece, indicating that Naden's plinth is similar (though not identical) to that of the statue of Theseus in Syntagma Square, Athens. Its classicism is reinforced by the epitaph from Virgil's Aeneid, as Aeneas considers a mural of the Trojan War: 'There are tears for [or 'of'] things and mortal things touch the mind' ${ }^{57}$

\footnotetext{
54 Thain, 'Birmingham's Women Poets', p. 49.

${ }^{55}$ Heslop's bust, unveiled in 1886, is by Francis John Williamson.

56 'The Late Miss Naden', Birmingham Daily Post, 8 October 1892, p. 4.

${ }^{57}$ Aeneid, Book I, 1. 462
} 
Characterising Naden's early death as an epic tragedy seems an odd choice as this heroism is defiantly male and martial, rather than female and intellectual.

The drawing together of the arts and sciences was integral to Naden's life's work, and the bust's positioning in Mason College Library captures this interplay (see figure 5). The relationship between art and science is shown by the carved books on which the bust rests. Naden's poetry is prioritised: the two spines facing outwards record the names of her poetic volumes, while the spine inscribed with 'Induction and Deduction' is turned away from the eyes of a cursory observer. Her 'memorial bust stood at one side of a great doorway in the German department of the library at Mason College, placed symmetrically with the bust of Heslop opposite'. ${ }^{58}$ This spatial interplay ensured that people encountering the sculptures would read the individuals as equals who merited equivalent remembrance. Indeed, this may account for the emphasis placed on Naden's poetry; she signifies the arts in balance with the sciences represented by Heslop. Although its plinth is fitted with an unusual turntable mechanism, which means that the reverse of the Naden bust can be viewed, its original positioning suggests that observers would not have been able to walk behind or around it. Today, Naden's bust is similarly in a tight corner of the Cadbury Research Library reading room. Thus, Naden comes to represent poetry over science.

As intended by Lewins, the bust functioned as a permanent signifier of Naden's presence at Mason College. In 1894, the principal of Mason College, R. S. Heath, was asked whether there had been any 'great women students.' He named Naden, taking the opportunity to refute Spencer's assessment of her death as indicative of the strain higher education places on women's bodies. ${ }^{59}$ Despite this positive remembrance, the next section shows how Naden's bust complicates this portrayal by nonetheless playing into a tradition of the doomed poetess.

\section{Memorialisation and Gender}

There are few documented reactions to Naden's bust. However, in April 1890, the 'Lady Correspondent' for the Sheffield Daily Telegraph wrote: 'Several visitors from Birmingham who had known that talented young lady during here $[$ sic $]$ residence there had expressed great

\footnotetext{
${ }^{58}$ James R. Moore, 'The Erotics of Evolution: Constance Naden and Hylo-Idealism', in One Culture: Essays in Science and Literature, ed. by George Levine (Madison: University of Wisconsin Press, 1987), pp. 225-57 (p. 255).

${ }^{59}$ G. W. T., 'Do Women Study Science? An Interview with R. S. Heath', Woman's Signal, 25 October 1894, pp. 258-59 (p. 259).
} 
satisfaction with the life-like work which Mr. Tyler has produced. ${ }^{, 60}$ By comparing the bust to the photographs of Naden, taken in Birmingham c.1887 (see figures 2 and 3b), it can be agreed that there is a decent likeness. Tyler does not shy away from portraying Naden's distinctive features that differ from conventional Victorian ideals of feminine beauty: Roman nose, small mouth, and broad, high brow. The bust's gaze is slightly strabismic as her left eye gazes forward and her right eye looks slightly towards the right. This differs from the standing photographic portrait (on which the bust appears most closely based) in which she gazes fixedly to the left, her expression serious and focused. (One can understand why Hughes refers to her 'highly intellectual face brought out by the well-known Whitlock portrait'.) ${ }^{61}$ Tyler's bust portrays Naden with a softer, distant gaze, fashioning her as a more wistful figure; poetess rather than scientist.

Deborah Lutz has identified the troubled status of photographs as relics during the late nineteenth century, suggesting that they were deemed 'unstable' as 'representations of the dead, as holders of memory' and documenting the attendant need for retaining more tangible physical remains. ${ }^{62}$ The multi-layered attempts to portray Naden speak to this urge to memorialise and allude to classical traditions representative of immortality. The original photograph of Naden taken by Henry Whitlock was quasi-posthumous at the point of creation. Hughes explains that 'friends and admirers of Miss Naden owe a debt of gratitude to Dr. R. W. Dale, who advised Mr. Whitlock to ask her to sit before her Indian journey, and this life-like photograph was the result ${ }^{63}$ Had Naden not survived her travels, these photographs would have become her memorial. Following Naden's death, Stodart engraved one of these photographs, included as a frontispiece to Memoir. The engraving is the most reproduced image of Naden, first appearing on 4 January 1890 in the Women's Penny Paper's 'In Memoriam'. ${ }^{64}$ Notably, it is with a cutting of this printed image that Michael Field (Katharine Bradley and Edith Cooper) marked Naden's death in their journal. ${ }^{65}$ However, the image's permanence was deemed insufficient, hence the creation of the bust.

\footnotetext{
60 'From our Lady Correspondent. London, Wednesday', Sheffield Daily Telegraph, 1 April 1890, p. 5.

${ }^{61}$ Hughes, Memoir, p. 8

${ }^{62}$ Deborah Lutz, Relics of Death in Victorian Literature and Culture (Cambridge: Cambridge University Press, 2015), p. 159

${ }^{63}$ Hughes, Memoir, p.8.

64 'In Memoriam', Women's Penny Paper, 4 January 1890, p. 125. It reappeared in 'Induction and Deduction', Women's Penny Paper, 2 Aug 1890, p. 488 and 'In Memoriam', Mason College Magazine, February 1890, p. 48 .

${ }^{65}$ Naden and Edith Cooper were family friends. Michael Field, 'Works and Days,' BL Add. MS. 46777, fol. $127 \mathrm{v}$ (30 December 1889).
} 
This series of representations in different media expresses the desire to commemorate Naden with a lasting memorial.

In the transition from photograph, to etching, to sculpture, we can trace various decisions about gendering Naden. In the engraving, Naden is decontexualised - she loses her desk and book (the accessories of Whitlock's photographs). The bust further transforms Naden from a contemporary woman into a classicised figure. This decision reflects nineteenth-century debates regarding the mixing of 'classicising form and modern references' in sculpture. ${ }^{66}$ Whilst 'statues of contemporary men in classical drapery were declared anachronistic and even laughable', modern costume was also 'condemned as antithetical to sculptural aesthetics: ugly, awkward, and with none of the grace and beauty of classical drapery ${ }^{67}{ }^{67}$ Tyler's stylistic choices suggest that he took the latter view, employing classicising elements to commemorate Naden as a timeless intellectual figure.

The bust does service to Naden as a philosopher and poet by setting her within a Hellenic tradition, and specifically moulds her into a poetess by participating in a wider tradition of depicting women poets. The lyre and the laurels link back to Sappho whose life was also famously cut short. Portrayals of Sappho and her death were obsessively produced in the eighteenth and nineteenth centuries and the 'last song' of Sappho proved a popular subject for Victorian women poets, including Hemans, Letitia Elizabeth Landon, Barrett Browning, Augusta Webster, and Christina Rossetti. ${ }^{68}$ As Margaret Reynolds notes, rehearsing Sappho's suicide 'ambivalently makes the writer simultaneously subject and object, like her text. The suicide is poised between self-construction and self-destruction, ${ }^{69}$

This ambivalence is embodied in sculptural representations of Sappho and the dead poetess. Susan Brown observes how John Gibson's Sappho (c. 1834) 'aestheticizes and commodifies' the suicidal poetess; she 'droops and sinks, threatening (though not quite managing) to drop the instrument that represents her poetic calling, ${ }^{70}$ Relatedly, posthumous depictions of the Romantic poet Mary Tighe are, Samantha Matthews remarks, notable for the 'ambiguous positioning of the feminine corpus as both morbid and vital, materially

\footnotetext{
${ }^{66}$ Martina Droth, Jason Edwards, and Michael Hatt, 'Introduction,' Sculpture Victorious: Art in an Age of Invention, 1837-1901 (New Haven: Yale University Press, 2014), p. 45.

${ }^{67}$ Droth et al, Sculpture Victorious, 45.

${ }^{68}$ Yopie Prins, Victorian Sappho (Princeton, NJ: Princeton University Press, 1999), pp. 174-245.

${ }^{69}$ Margaret Reynolds, “I lived for art, I lived for love”: The Woman Poet Sings Sappho's Last Song', in Victorian Women Poets: A Critical Reader, ed. by Angela Leighton (Oxford: Blackwell, 1996) pp. 277-306 (p. 291).

${ }^{70}$ Susan Brown, 'The Victorian Poetess', in The Cambridge Companion to Victorian Poetry, ed. by Joseph Bristow (Cambridge: Cambridge University Press, 2000), pp. 180-202 (p. 183).
} 
embodied and transcendent, mortal and immortal' ${ }^{71}$ These representations culminate in a tomb designed by John Flaxman in 1814-15, 'embodying Tighe [...with] an idealized masklike face recalling the posthumous frontispiece portraits; flowing neoclassical yet shroudlike drapery'; her death is romanticised, her legacy as a poet erased. ${ }^{72}$ Matthews comments that these depictions demonstrate ' $[\mathrm{t}]$ he stages of temporal and reprographic removal from a lost and dead "original"' and "signify the poetess as mythic, remote, and abstracted'; she becomes 'a romantically styled, unindividualized icon of "poetic" femininity; a modern Sappho' ${ }^{73}$. The classicising elements of Naden's bust therefore troublingly align her within the doomed poetess tradition.

The sculptural bust as fragment also connects Naden's bust to Sappho. Many Ancient Greek busts were originally part of complete statues and violently fragmented through the passage of time. Page DuBois links these sculptural remains (the torso of the Venus de Milo, for example) to the fragmented lyrics of Sappho. ${ }^{74}$ Considering Naden's bust as a fragment opens up a reading that focuses on loss rather than wholeness; an intentionally failed or incomplete memorialisation. The bust-as-fragment is appropriate for a woman cut off in her prime. Like Sappho, Naden's all-too-brief career came to symbolise a tragedy for educated women in the late nineteenth century. In this sense, Tyler's bust symbolises the loss of Naden and the violent severing of women's potential at this crucial moment for female intellectual endeavour. The link to Sappho remains ambivalent; whilst it might connect Naden to another female genius, it also suggests that a balance between love, health, reproduction, fame and artistic achievement cannot be struck. The bust instantiates a disconnection between mind and body, obscuring Naden's scientific endeavours and presenting the visage of a timeless (and doomed) poetess.

The 'Lady Correspondent' notes that bust was created through 'careful study of [Naden's] character from her poems'. ${ }^{75}$ This is the standard rhetoric surrounding the poetess, whereby women's poetry is deemed to be an outpouring of feeling. ${ }^{76}$ Tyler's supposed ability to use Naden's poems to create an accurate likeness is particularly fascinating because she rarely creates a direct link between poet and poetic voice. In many instances Naden

\footnotetext{
${ }^{71}$ See, for example, George Romney's 'Portrait of Mary Tighe' (1795) and 1812 engraving by Edward Scriven Tighe. Samantha Matthews, Poetical Remains: Poets' Graves, Bodies, and Books in the Nineteenth Century (Oxford: Oxford University Press, 2004), pp. 77-78, 86.

72 Ibid., p. 100.

${ }^{73}$ Ibid., pp. 86-87.

${ }_{75}^{74}$ Page DuBois, Sappho is Burning (Chicago: University of Chicago Press, 1995), pp. 31-54.

75 'Lady Correspondent', 30 January 1890.

${ }^{76}$ See Isobel Armstrong, Victorian Poetry: Poetry, Poetics and Politics (London: Routledge, 1993), pp. $332-67$.
} 
substitutes the authorial 'I' with a more unified and inclusive 'we', providing her lyrics with a universal quality indicative of philosophical detachment. This is particularly evident in the 1881 sonnets: in 'Speech and Silence' she describes how 'In stillness we must win our deepest lore', while in 'Illusions' she observes that 'We speak in fables, and are compassed round / With poesy'. ${ }^{77}$ Moreover, distancing techniques such as the dramatic monologue ('The Carmelite Nun'), the comic register ('Love Versus Learning'), and framing devices ('A Letter') frequently prevent the reader feeling as though they are getting beneath the surface of Naden's well-crafted public persona. ${ }^{78}$ Stainthorp has shown how Naden's poetry interrogates the lyric 'I' and favours alternatives to it, encouraging her readers to reconsider the function of the poet. ${ }^{79}$ To suggest, therefore, that Naden's true self was visible through her poetry is both apposite and misleading; while Naden's selfhood was often elided, her use of masking techniques is itself indicative of her desire to be understood as an objective thinker rather than one who divulges feelings in verse.

To reflect on Naden's persona further, we return to her early self-portrait poem. The bust's marble features fit with this equivocal description that Naden wrote during her adolescence but never published:

Eyes of grey, complexion fair, Brow not high, but broad \& square, Coronet of dark-brown hair, Cheeks just tinted with the rose, Large, \& not quite Grecian, nose, Mouth that some consider small, Stature that you could not call Either short or very tall, But about the middle height, With a figure rather slight; I have shown the outward frame Tell me now the maiden's name. ${ }^{80}$

These features are identifiable in the two extant photos of Naden. What is most notable, however, is her inability to describe herself as one thing or another; whether describing her 'not high' brow, 'not quite Grecian' nose, or neither 'short [n]or very tall' stature, she resolutely inhabits a middle-ground. The equivocation underlying this poem indicates her uneasiness with labelling herself, and this takes on a new layer of meaning upon the creation

\footnotetext{
${ }^{77}$ The Complete Poetical Works of Constance Naden, ed. by Robert Lewins (London: Bickers and Son, 1894), pp. 131, 134.

${ }_{78}$ Ibid., pp. 22-24, 88-90, 34-35.

${ }^{79}$ Stainthorp, Constance Naden, chapter 4.

${ }^{80}$ Poems 1875-6-7, p. 82.
} 
of a bust that imbues her features with an absolute level of fixity. The playful but selfdepreciating tone may be read in parallel with her wariness of occupying the poet role. This is the theme of other early poems, such as 'The Poets' Mountain' in which she describes the lofty 'spot where poets dwell' but concludes:

Though to the poet's awful height

My feet shall never climb,

I yet may roam, with footsteps light

The humble paths of Rhyme. ${ }^{81}$

This perspective aligns with her unwillingness to be fixed to one lyric or philosophical position or persona. Despite youthful expressions of physical and personal ambiguity, Naden became set in stone. However, during the twentieth century, Naden's bust acquired a level of anonymity while concurrently serving as a symbol for female academic achievement.

\section{The Naden bust today}

In 1900, Mason College received its Royal Charter and became the University of

Birmingham. In 1909, the university expanded across two locations; most faculties moved to a new Edgbaston campus, but Naden's bust remained in the library of the Arts and Law building in the heart of the city (Victoria Square). In the 1960s the Arts Building opened on the Edgbaston campus, leaving Mason College to be demolished in 1964 so that the (infamously) brutalist Central Library could be built in its place (now also demolished). The bust was thus forced to move position for the first time since 1890. It was taken to the Edgbaston outpost of the Shakespeare Institute, Westmere House. It is here that we have the first record of how people responded to the object in situ. In 1987, James Moore recounted how:

the sculptures were separated. Heslop now inhabits the room named after him in the University Library, which holds rare books and archives. Constance stands forlornly on the staircase in the Shakespeare Institute, 'so calm, so child-like, so marble-cold.' She is best remembered today by those who adorn her and, in search of passing luck, unselfconsciously rub her nose. But as a hat rack or talisman, the graven goddess ill serves her donor's purpose. ${ }^{82}$

\footnotetext{
${ }^{81}$ Ibid., pp. 1-2.

${ }^{82}$ Moore, pp. 255-56. The quotation identifies Naden with the title character of 'The Story of Clarice', Complete Poetical Works of Constance Naden, p. 273.
} 
One wonders how much these students knew of Naden, and if her academic excellence fed into the development of this ritual. Even divorced from this specificity, however, the iconography of a bust resting on a pile of books echoes the piles of texts on a student's desk the rituals of university study largely unchanged in the intervening decades. Is this really indicative of the bust coming to 'ill serve' its purpose? The object has ensured that Naden's physicality has endured. Its presence stimulates a sense of connection with, and interest in, Naden that would otherwise be ephemeral, relying on serendipitous contact with her published works that are rarely found in bookshops or on library shelves.

In 1992, the Shakespeare Institute moved to Stratford-upon-Avon. ${ }^{83}$ Naden's bust subsequently took up residence in the University of Birmingham's library, once again reunited with Thomas Heslop. Then, upon the opening of the Cadbury Research Library in 2010, the bust took up its current position in the university's special collection's reading room. An adjoining room houses the institution's calendars (cataloguing Naden's exam results and academic prizes), while the nearby archives hold all her published works. In 2015, the first extant manuscript materials written by Naden were discovered and, fittingly, acquired by the Cadbury Research Library. Naden's personal notebooks - our first glimpse of her thoughts unfiltered by the publication process - can now be read under the gaze of her most public incarnation. ${ }^{84}$

While Naden's physical manifestation endured across the twentieth century, her writings have not similarly maintained a position in the public or scholarly consciousness. Since the late 1980s, Naden's poetry has been rediscovered by scholars interested in the intersections between literature and science, figurations of the New Woman, and Victorian atheist thought. Naden was a thinker who traversed disciplines, drawing upon and synthesising the methodologies and themes of poetry, philosophy and science. Were we to take Naden's bust at face value - its classical and aesthetic symbolism underwritten by the titles of Naden's poetry - the viewer may not discern this multifaceted intellectual career. However, by attending to it more closely, turning the object on its plinth to read the hidden book title and locating the bust in its physical contexts over time, a far richer and more accurate view becomes apparent.

Naden's bust began as an object that commemorated the loss of a young woman by her friends and colleagues, attesting to her impact on the intellectual community of late

\footnotetext{
${ }^{83}$ It is now situated at Mason Croft, the former residence of another nineteenth-century woman writer, Marie Corelli.

${ }^{84}$ For details of this acquisition see Clare Stainthorp, 'On the Discovery of a Sequence of Constance Naden's Notebooks: Finding her Voice, 1875-79’, Victorian Poetry, 56 (forthcoming 2018).
} 
nineteenth-century Birmingham. During the twentieth century it lost much of its personal resonance, becoming an icon of good luck, divorced from Naden's individual achievements, the plinth's details left unparsed. As academics sought to reposition women writers within the history of literature, Naden's works have been brought back to light. The bust's current greyish tinge arose from a misguided attempt at cleaning the marble during its time at Westmere House; staff in the Research and Cultural Collections at the University of Birmingham are currently considering how to undo this damage. ${ }^{85}$ A similar narrative of blurred features brought back into focus underlies our reading of this sculpture and its history, as it sits in a reading room overseeing new research that seeks to rejuvenate Naden's legacy.

\section{Coda}

On International Women's Day 2017, a newly commissioned photograph of the Naden bust (figure 6) was one of a series of images projected upon 'Old Joe', the iconic clock tower at the heart of the Edgbaston campus. Part of the 'Making Space' project, Liz Hingley sought to 'place images of inspirational women associated with the University of Birmingham at the very centre of campus and create a lasting legacy for the future' ${ }^{86}$ This act acknowledges Naden's position within the history of the institution. Her memorial bust thus reasserts itself in a new century as a signifier for female intellectual achievement and aspiration.

\section{Figure Captions}

Figure 1: Portrait bust of Constance Naden and plinth, William Henry Tyler (1890). University of Birmingham Research and Cultural Collections, BIRRC-A0436.

Figure 2: Constance Naden photographic portrait, Henry Whitlock (c.1887). Further Reliques of Constance Naden: Essays and Tracts for our Times, ed. by George M. McCrie (London: Bickers and Son, 1891), frontis.

Figure 3a: Constance Naden portrait engraving, G. J. Stodart. William R. Hughes, Constance Naden: A Memoir (London: Bickers and Son, 1890), frontis.

Figure 3b: Constance Naden portrait, c.1887. Private collection (C) Julian Rees.

Figure 4a: Detail, base of the Constance Naden portrait bust.

\footnotetext{
${ }^{85}$ Personal correspondence with Helen Fisher (University Archivist, Cadbury Research Library). Thanks to Chris Penney (former Head of the University of Birmingham Special Collections) for relating the bust's movements during the 1990 s.

${ }^{86}$ The image also appeared on the front page of the exhibition brochure. 'Making Space: Celebrating Women at the University of Birmingham', University of Birmingham $(2017)<\mathrm{http}$ ://www.birmingham.ac.uk/strategicframework/Resources/making-space.aspx $>$ [accessed 20 March 2018]
} 
Figure 4b: Detail, reverse of the base of the Constance Naden portrait bust.

Figure 5: Photograph of the library at Mason College showing the Heslop bust (left) and the Naden bust (right), Bedford Lemere \& Co., London (1897). (C) Cadbury Research Library, University of Birmingham, UB/MC/N/2/2.

Figure 6: 'Portrait bust of Constance Naden, William Henry Tyler, 1890 from the Research and Cultural Collections' (C) Liz Hingley (2017). 




$285 \times 506 \mathrm{~mm}(300 \times 300 \mathrm{DPI})$ 


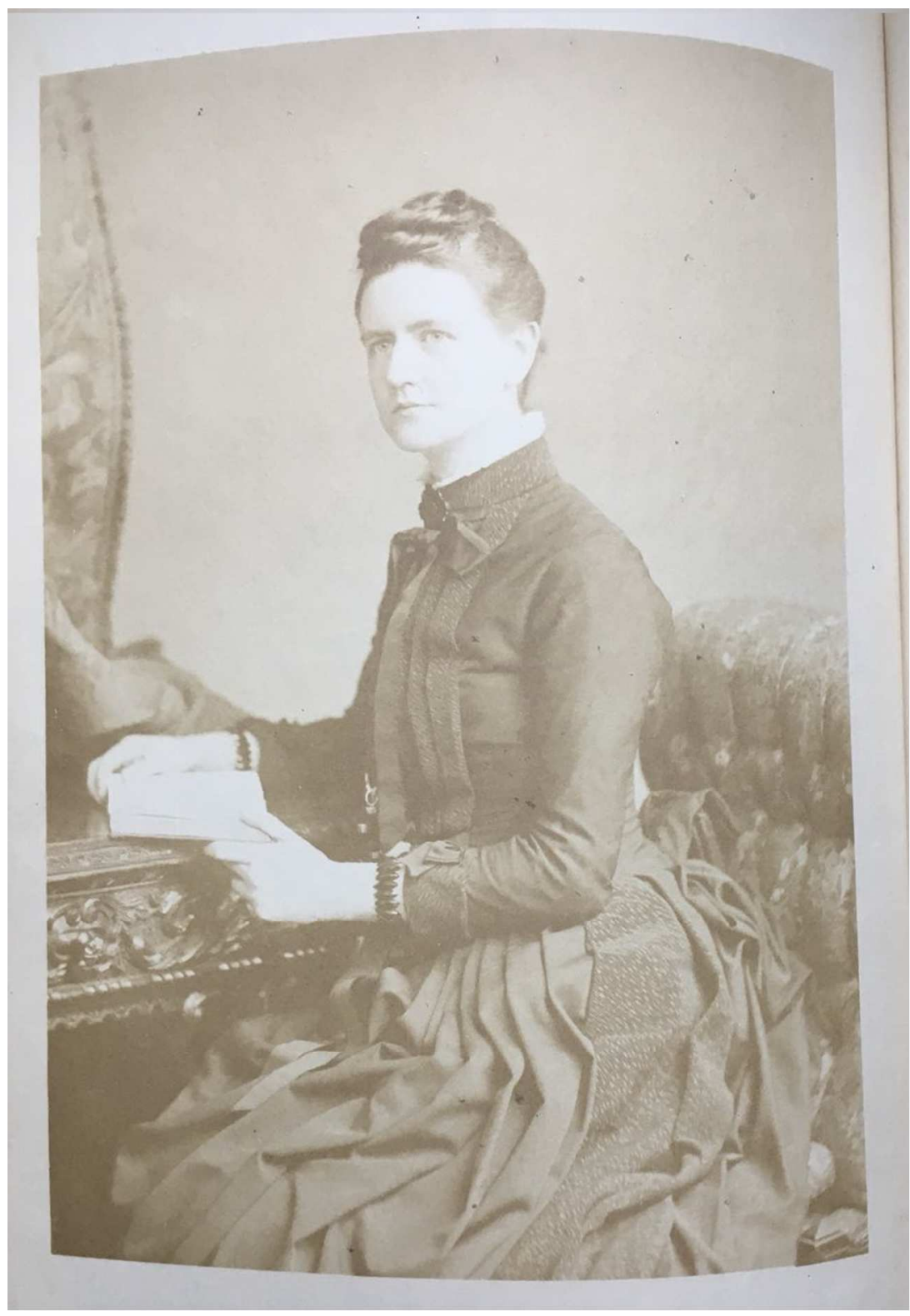

$78 \times 113 \mathrm{~mm}(300 \times 300 \mathrm{DPI})$ 




$218 \times 358 \mathrm{~mm}(300 \times 300 \mathrm{DPI})$ 


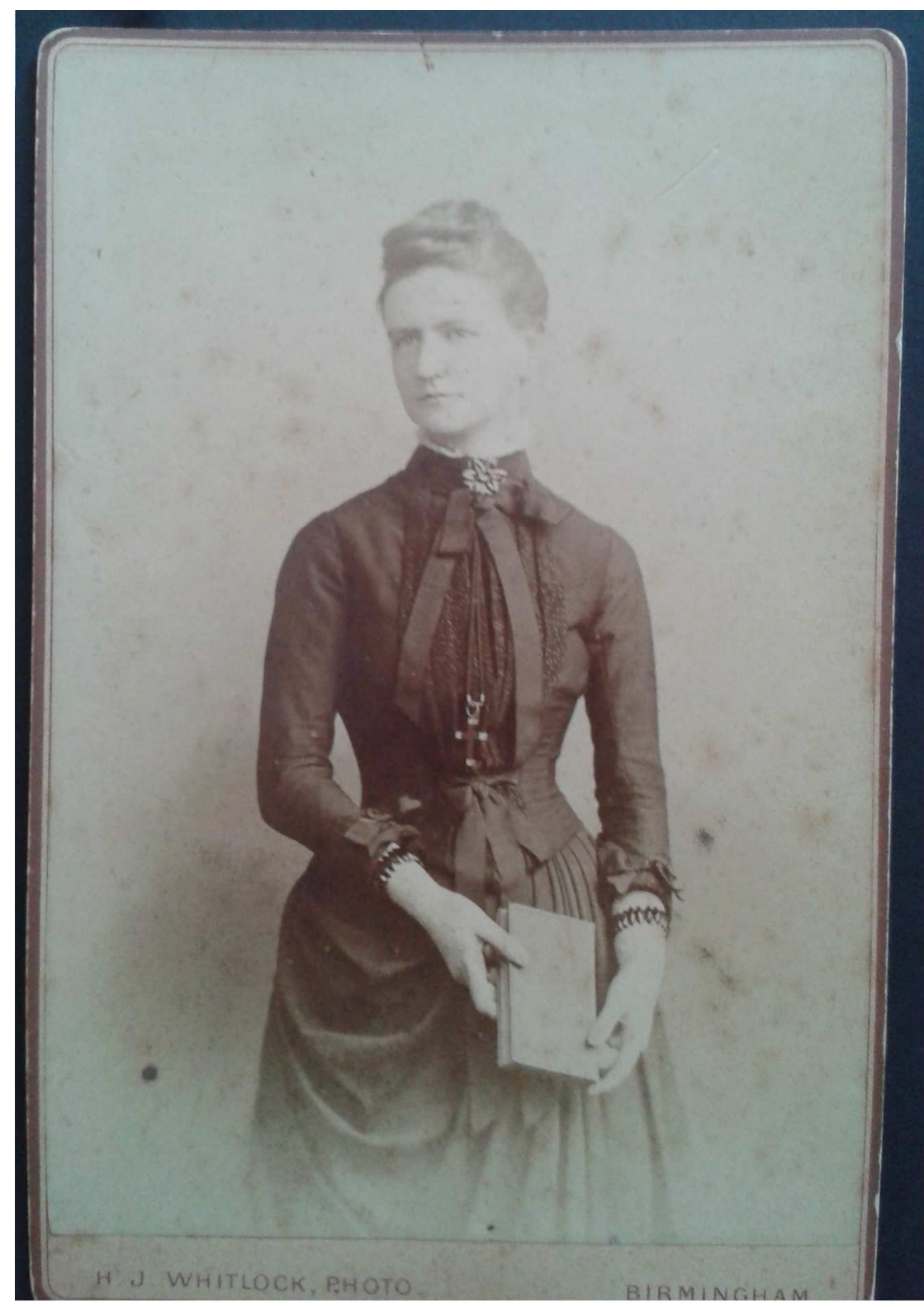

$142 \times 202 \mathrm{~mm}(300 \times 300 \mathrm{DPI})$ 




$506 \times 285 \mathrm{~mm}(300 \times 300 \mathrm{DPI})$ 


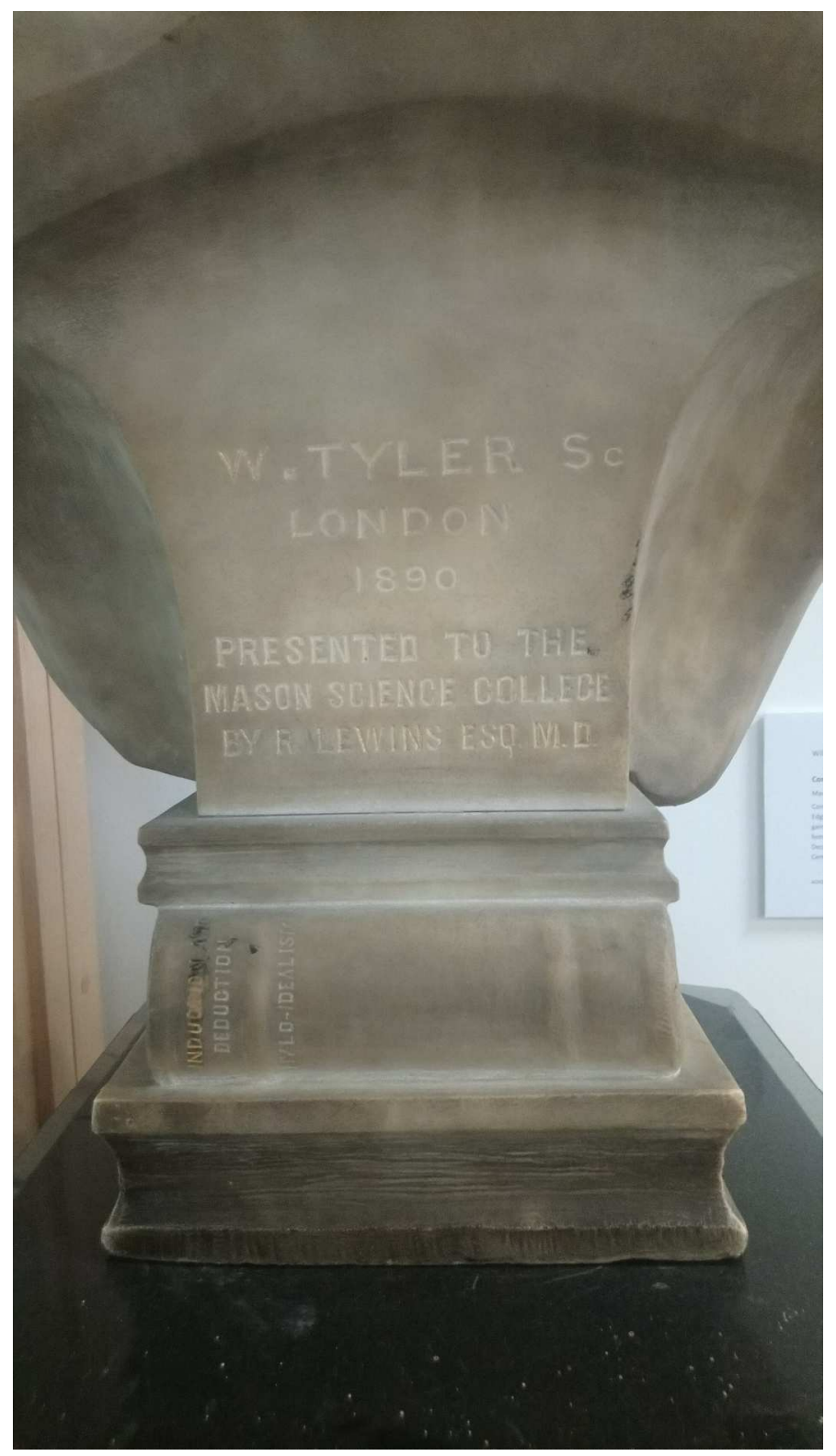

$285 \times 506 \mathrm{~mm}(300 \times 300$ DPI $)$ 


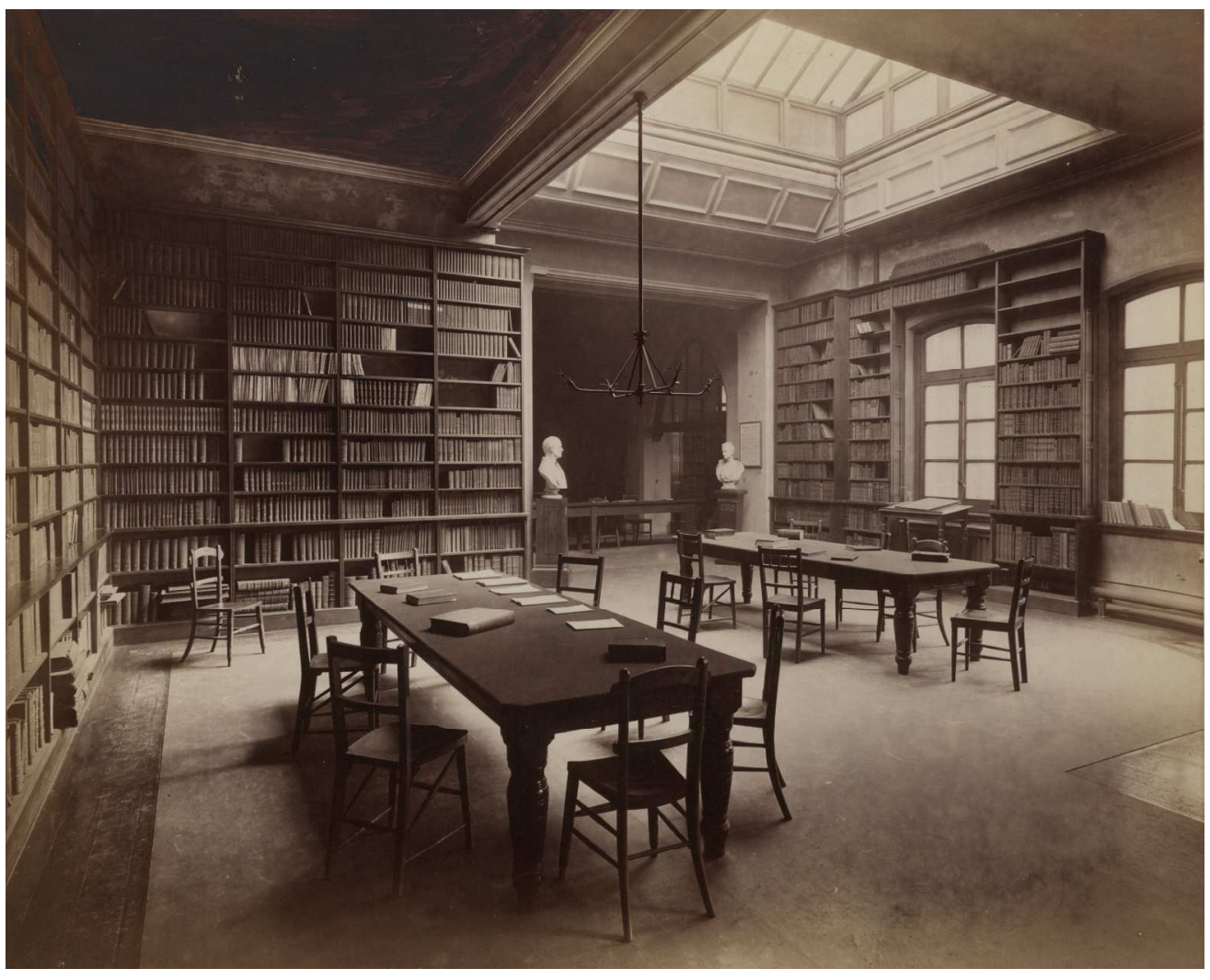

$298 \times 238 \mathrm{~mm}(300 \times 300$ DPI $)$ 


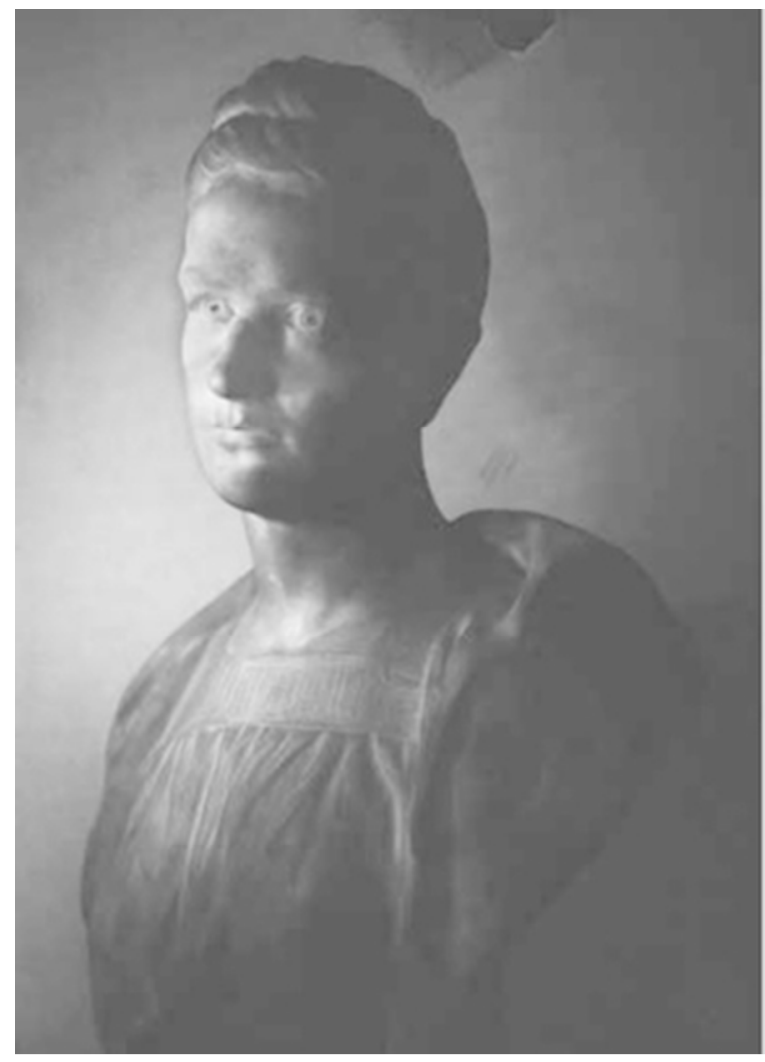

$24 \times 33 \mathrm{~mm}(300 \times 300$ DPI $)$ 